\title{
APPRAISAL OF REAL ESTATE WITH VARIOUS FUNCTIONS IN THE CONTEXT OF SUSTAINABLE DEVELOPMENT
}

\author{
ADAMCZYK Tomasz ${ }^{\text {a }}$, BIEDA Agnieszka ${ }^{\text {a, } *, \text { PARZYCH Piotr }}{ }^{\text {a }}$ \\ ${ }^{a}$ AGH University of Science and Technology, Faculty of Mining Surveying and Environmental Engineering, \\ A. Mickiewicza Av.30,30-059 Krakow, Poland, e-mail: tomasz.adamczyk@agh.edu.pl, agnieszka.bieda@agh.edu.pl, \\ piotr.parzych@agh.edu.pl
}

Received: 21.02.2019 / Accepted: 23.03.2019/ Revised: 27.04.2019 / Available online: 31.05.2019

DOI: $10.2478 /$ jaes-2019-0001

KEY WORDS: parametric model, conditional model, real estate function, appraisal of real estate, sustainable development.

\begin{abstract}
:
The value of a piece of real estate depends on the purpose it is used for and on its function in planning documents. Unfortunately, current land development trends and the provisions of the law that are applicable in these documents often lead to real estate with heterogeneous functions. The valuation of such properties requires a special approach. One method is to divide the prices of real estate similar to the appraised real estate into components that correspond to areas with certain functions. The aim of this paper is to present statistical methods that can facilitate such a solution. The valuation models (parametric and conditional) presented in this article come from geodetic methods for the reconciliation of results. The presented calculations suggest that it is necessary to verify whether the heterogeneous functions of real estate should be considered in its appraisal.
\end{abstract}

\section{INTRODUCTION}

The discussion of sustainable development has its roots in the definition elaborated on by the Brundtland Commission in its critical publication "Our Common Future". This definition is often quoted in its shortened form: "Sustainable development is development that meets the needs of the present without compromising the ability of future generations to meet their own needs". We need to recognise, however, that this definition of sustainable development is not complete (Barkemeyer et al., 2014). Sustainable development is hard to describe, and even more difficult to attain (Waage et al., 2015).

A widely accepted definition of sustainable development is presented by means of the "three circles" model (Barkemeyer et al., 2014). The model incorporates economic, social, and environmental aspects, which are often pillars of sustainable development. Unfortunately, both the subject literature and an analysis of political situations indicate that sustainable development without compromises between economic, social, and ecological objectives is a rarity (Gupta and Vegelin, 2016). This is because industrial development in the modern world cannot be avoided (Busko and Szafranska, 2018) and the world strives for compromise in favour of economy at the expense of social and ecological issues (Lorek and Spangenberg, 2014).

Attempts to provide sustainable and healthy development for people should be preceded by the implementation of systems that prevent poor land-use planning (Choi et al., 2016). They should supply tools that regulate land use and monitor the actions local authorities take to plan spaces where people live. In order to manage the earth, which is one of our most precious natural resources, spatial planning is often used (Fuseini and Kemp, 2015). The idea of sustainable development requires that spatial planning integrates economic growth with the environment protection and social progress. Such integration should occur between differing sectors of the economy, social subjects, and countries (Hajer et al., 2015; Stafford-Smith et al., 2017).

To this end, most countries issue documents that are necessary to achieve sustainable development (Grădinaru et al., 2017). These documents are usually the basis for determining spatial planning objectives, and are used to prepare documents that facilitate spatial development management on all levels (national, regional, and local), which is confirmed by the descriptions of spatial planning systems given in (KwartnikPruc and Przewięźlikowska, 2007; Koreleski, 2009; Cieślak, 2010; Golej, 2012; Topczewska, 2012; Bieda and Parzych, 2013; Krajewska et al., 2014; Tölle, 2014; Bieda et al., 2018).

The outcome of spatial planning is always a division of space into areas that have distinct functions. The deployment of areas depends on many factors (Chang and Ko, 2014). Obviously, the simplest approach is to determine the function of areas that have not been developed in any form (Adamczyk et al., 2014). Because planning does not occur in a vacuum, planning documents need to consider the existing spatial development. As a result, even though lines that separate areas of different function should be compatible with cadastral boundaries (Bieda et al., 2012), filling the actual planning space is not

\footnotetext{
*Corresponding author: Agnieszka Bieda, e-mail: agnieszka.bieda@agh.edu.pl
} 
always possible, leading to the creation of real estate that has different functions (Bieda, 2017; Bieda, 2018).

Spatial planning documents comprise a starting point for deciding about the future development of human surroundings. Consistency between planned and actual spatial development is expected (Grădinaru et al., 2017). The heterogeneous function of real estate may cause it to be more difficult to achieve this consistency than with real estate that has a single function. One of the reasons for this is economic. A plot with contrasting functions cannot be used as a whole for the intended building purposes. Potential buyers may expect such a piece of real estate to be cheaper than one they could develop entirely. An appraisal of real estate that considers such an expectation is definitely more demanding.

In line with the economic development of society, the need arose to work out an efficient and effective approach to the valuation of real estate (Chen et al., 2017). Among the many values of property, the most desired is the market value (Źróbek and Walacik, 2017). Its definition was formed internationally and then entered into the legislative acts of many countries. According to this definition, the market value is "based on the highest and best use of the property", which is "the most probable use of the property which is physically possible, appropriately justified, legally permissible, financially feasible, and which results in the highest value of the property being valued" (Grzesik and Źróbek, 2017).

The expression "legally permissible" became problematic in countries which have documents that divide human surroundings into areas with different functions at the local level of spatial planning. Appraisers in the United States of America claim that market value assessed on the basis of the "highest and best use" may reflect the future change of land use. The only condition to apply this method is the necessity to establish whether and when such a change occurs. European appraisers, in contrast, are not confident whether a function which is currently not legitimate will be allowed in the future. Their interpretation leads to the introduction of the concept of "hope value", which is the difference between the use value and the price the market could pay for the property in the hope of more valuable use (Renigier-Biłozor and d'Amato, 2017). Nevertheless, no matter what the definition of the market value is, the correct valuation of real estates with heterogeneous function depends on the inclusion of these functions in the valuation process.

Although the valuation methods depend on the individual experiences of countries, the great majority of these methods depend on comparing the assessed real estate with other pieces of real estate (Pagourtzi et al., 2003). Properties to which the valuated real estate is compared should be in similar location, should have similar legal status, function, use, and other features that affect their value. The above-mentioned features may be divided into two groups (Zyga, 2012). The first group incorporates features that define similarities. These features include legal status, function, and the use of the real estate. The second group includes features that enable the correction of the price level in order to determine the marker price of the appraised property. They will vary depending on the type of the property. However, typically the repetitive cost elements are location, surroundings, access roads, and parcel shape (Czaja, 2001; Putek, 2001; Adamczewski, 2006; Bieda and Brzozowski, 2007; Foryś and Kokot, 2008; Rącka, 2009;
Basista, 2010; Radzewicz and Wiśniewski, 2012; Batóg et al., 2017).

All these factors should be considered in every valuation of real estate (Cellmer et al., 2014). This task is often hindered by the complex and heterogeneous nature of the property (Dawidowicz et al., 2014), as well as diversity and overlapping attributes (Renigier-Biłozor et al., 2017). In particular, an incorrect designation of the property function may lead to an erroneous appraisal (Adamczyk and Bieda, 2014).

Although valuation standards are available, experts increasingly notice shortcomings when applying traditional methods of real estate appraisal (Maliene, 2011). This happens when one needs to value the real property with divergent functions, and this appraisal is conducted by comparing the valuated property to other properties that also have heterogeneous functions. These functions, however, differ from the function of the appraised real estate - they cover slightly different areas, or the proportions of the identical areas surface in various properties differ (Bieda, 2017; Bieda, 2018).

When property appraisers are made to use the valuation method with a superficial mathematical description, the subjective decisions that make the appraisal unreliable cannot be avoided. Thus, innovations in the methodology of property appraisal are required (Maliene, 2011). Therefore, the aim of this paper is to present statistical methods for the appraisal of real estate with various functions. The discussed valuation models come from geodetic methods for the reconciliation of results (Czaja, 1997; Wiśniewski, 2005; Preweda, 2013). Their advantage is the possibility to separate from the unit prices of real estate with heterogenous functions, and the unit prices of areas that have a specific function (Bieda, 2017; Bieda, 2018).

\section{MATERIALS AND METHODS}

In order to evaluate the usability of statistical methods that allow for separation from unit prices of real estate with heterogeneous functions and the unit prices of areas that have a specific function, the value of land property which consists of one, undeveloped parcel with a square area of $3200 \mathrm{~m}^{2}$ was assessed. The property lies in an area designed for multidwelling houses (MD), development for commercial and public services purposes (S), public roads (PR), and controlled public greenery areas (PG). The value was assessed using parametric and conditional models.

\subsection{Data for appraisal and market analysis}

The data necessary for the property valuation was obtained from the Geodesy Department of Krakow City Hall (Register [...], 2016). They were used to create a database of similar properties that are presented in table 1.

In order to determine what effect individual market features and time have on property prices presented in table 1, Pearson correlation coefficients (r) and their square values were calculated and are juxtaposed in table 2 .

The values in table 2 indicate that time does not influence property value (Czaja, 2001). Thus, it is not necessary to correct prices because of a valuation date that is 24 months after the price of the first similar property has been established. 
Other features have only a moderate impact on prices (Parzych and Czaja, 2015)

The Pearson correlation coefficient will be used to determine the weight share $(\mathrm{k})$ of individual features that describe the property. On the analysed real estate market, prices depend $27 \%$ on the parcel features, $26 \%$ on its surroundings, and $23 \%$ on the location and access road.
In documents received from the Cracow City Hall, all these properties were described as designed for multi-dwelling houses (MD). The verification of planning documents revealed, however, that their function is not always uniform. The surface areas of individual parcels were determined with cartometric measurements and are shown in graphical appendices attached to the documents that indicate the property function. They are given in table 3 .

Table 1. Prices of the valuated property (V) along with features and prices of properties that are similar to the assessed property (1-18)

\begin{tabular}{|c|c|c|c|c|c|c|c|c|}
\hline No. & $\begin{array}{c}\text { time } \\
{[\text { month] }}\end{array}$ & location * & $\begin{array}{l}\text { surround- } \\
\text { dings * }\end{array}$ & $\begin{array}{l}\text { access } \\
\text { road }^{*}\end{array}$ & $\begin{array}{c}\text { parcel } \\
\text { shape * }\end{array}$ & $\begin{array}{c}\text { property } \\
\text { price } \\
{\left[\text { PLN }{ }^{* *}\right]}\end{array}$ & $\begin{array}{c}\text { surface } \\
\text { area }\left[\mathbf{m}^{2}\right]\end{array}$ & $\begin{array}{c}\text { unit price } \\
{\left[\mathbf{P L N} * * / \mathbf{m}^{2}\right]}\end{array}$ \\
\hline 1 & 0 & 1 & 1 & 1 & 0 & 940,000 & 3,490 & 269 \\
\hline 2 & 1 & 2 & 2 & 1 & 1 & $1,500,000$ & 4,220 & 355 \\
\hline 3 & 4 & 1 & 1 & 1 & 1 & 890,000 & 2,690 & 331 \\
\hline 4 & 6 & 2 & 2 & 1 & 2 & $1,700,000$ & 4,840 & 351 \\
\hline 5 & 7 & 1 & 2 & 1 & 1 & $1,000,000$ & 3,430 & 292 \\
\hline 6 & 7 & 1 & 1 & 2 & 1 & 900,000 & 2,490 & 361 \\
\hline 7 & 8 & 1 & 1 & 0 & 0 & 700,000 & 2,360 & 297 \\
\hline 8 & 9 & 1 & 1 & 1 & 2 & 990,000 & 3,370 & 294 \\
\hline 9 & 10 & 1 & 1 & 1 & 1 & 675,000 & 2,330 & 290 \\
\hline 10 & 12 & 2 & 1 & 1 & 2 & $1,400,000$ & 3,570 & 392 \\
\hline 11 & 12 & 2 & 2 & 2 & 1 & $1,100,000$ & 2,850 & 386 \\
\hline 12 & 15 & 2 & 1 & 1 & 1 & 980,000 & 3,410 & 287 \\
\hline 13 & 18 & 2 & 2 & 1 & 2 & $1,530,000$ & 4,250 & 360 \\
\hline 14 & 19 & 2 & 1 & 1 & 2 & $1,300,000$ & 4,330 & 300 \\
\hline 15 & 20 & 1 & 1 & 0 & 0 & $1,200,000$ & 4,065 & 295 \\
\hline 16 & 20 & 1 & 2 & 1 & 2 & $1,400,000$ & 4,000 & 350 \\
\hline 17 & 22 & 2 & 2 & 2 & 1 & 980,000 & 3,080 & 318 \\
\hline 18 & 23 & 1 & 1 & 1 & 1 & 930,000 & 2,880 & 323 \\
\hline $\mathrm{V}$ & 24 & 1 & 1 & 1 & 1 & $?$ & 3,200 & $?$ \\
\hline
\end{tabular}

Table 2. Relation between property features and unit prices

\begin{tabular}{|c|c|c|c|c|c|}
\hline coefficient & time & location & surroundings & access road & parcel shape \\
\hline $\mathrm{r}$ & 0.04 & 0.46 & 0.43 & 0.44 & 0.47 \\
\hline $\mathrm{r}^{2}$ & 0.0016 & 0.2168 & 0.1875 & 0.1921 & 0.2249 \\
\hline $\mathrm{k}$ & - & 0.26 & 0.23 & 0.23 & 0.27 \\
\hline
\end{tabular}

Table 3. Surface areas of appraised parcels with specific function $(\mathrm{V})$ and properties that are similar to the appraised property (1-18)

\begin{tabular}{|c|c|c|c|c|c|}
\hline No. & $\begin{array}{c}\text { surface area of MD } \\
{\left[\mathbf{m}^{\mathbf{2}}\right]}\end{array}$ & $\begin{array}{c}\text { surface area of PR } \\
{\left[\mathbf{m}^{\mathbf{2}}\right]}\end{array}$ & $\begin{array}{c}\text { surface area of PG } \\
{\left[\mathbf{m}^{\mathbf{2}}\right]}\end{array}$ & $\begin{array}{c}\text { surface area of S } \\
{\left[\mathbf{m}^{\mathbf{2}}\right]}\end{array}$ & $\begin{array}{c}\text { parcel surface area } \\
{\left[\mathbf{m}^{\mathbf{2}}\right]}\end{array}$ \\
\hline 1 & 2,100 & 250 & 1,140 & 0 & 3,490 \\
\hline 2 & 3,300 & 520 & 0 & 400 & 4,220 \\
\hline 3 & 1,760 & 300 & 180 & 450 & 2,690 \\
\hline 4 & 3,700 & 40 & 400 & 700 & 4,840 \\
\hline 5 & 2,300 & 150 & 980 & 0 & 3,430 \\
\hline 6 & 2,200 & 290 & 0 & 0 & 2,490 \\
\hline 7 & 1,350 & 830 & 180 & 0 & 2,360 \\
\hline 8 & 2,000 & 0 & 870 & 500 & 3,370 \\
\hline 9 & 1,400 & 690 & 240 & 0 & 2,330 \\
\hline 10 & 3,350 & 220 & 0 & 0 & 3,570 \\
\hline 11 & 2,720 & 130 & 0 & 0 & 2,850 \\
\hline 12 & 2,150 & 610 & 650 & 0 & 3,410 \\
\hline 13 & 3,780 & 0 & 470 & 0 & 4,250 \\
\hline 14 & 3,100 & 0 & 1,230 & 0 & 4,330 \\
\hline
\end{tabular}




\begin{tabular}{|c|c|c|c|c|c|}
\hline No. & $\begin{array}{c}\text { surface area of MD } \\
{\left[\mathbf{m}^{\mathbf{2}}\right]}\end{array}$ & $\begin{array}{c}\text { surface area of PR } \\
{\left[\mathbf{m}^{\mathbf{2}}\right]}\end{array}$ & $\begin{array}{c}\text { surface area of PG } \\
{\left[\mathbf{m}^{\mathbf{2}}\right]}\end{array}$ & $\begin{array}{c}\text { surface area of S } \\
{\left[\mathbf{m}^{\mathbf{2}}\right]}\end{array}$ & $\begin{array}{c}\text { parcel surface area } \\
{\left[\mathbf{m}^{\mathbf{2}}\right]}\end{array}$ \\
\hline 15 & 2,310 & 115 & 980 & 660 & 4,065 \\
\hline 16 & 3,000 & 250 & 340 & 410 & 4,000 \\
\hline 17 & 2,070 & 0 & 620 & 390 & 3,080 \\
\hline 18 & 1,720 & 550 & 100 & 510 & 2,880 \\
\hline V & 2,100 & 250 & 300 & 550 & 3,200 \\
\hline
\end{tabular}

\subsection{Valuation algorithm in the parametric model}

The parametric model is based on the analysis of the total price for the entire property. The unit values of the land components are the estimated parameters here. The model may be used when the number of transactions (which stand for similar properties to the one being evaluated) is greater than the sum of all elements which are the components of the considered properties and the number of features which are the basis for the correction of the price level of properties entered into a database for comparison purposes. The parameters of this model are estimated with the least squares method. They are the basis for determining the unit value of areas with different functions, which comprise part of the analysed property. The obtained outcomes enable us to determine the market value of properties which are similar to the valuated property.

This model was used in real estate appraisal to evaluate the market value of built-up land properties (Adamczewski, 2006; Parzych, 2007; Parzych and Bydłosz, 2007; Adamczewski and Hopfer, 2008; Czaja and Parzych, 2008; Parzych, 2009a; Parzych, 2011; Adamczyk and Jasiołek, 2012; Parzych and Czaja, 2015; Bieda et al., 2016), agricultural and forest properties (Parzych, 2009a; Parzych and Czaja 2015) and the costs of erecting and the use of buildings (Adamczyk and Dąbrowski, 2010; Bydłosz et al., 2011). It was proposed to evaluate real properties with various functions in (Bieda, 2017).

In order to divide the transaction price of land property that lies within the area of various functions into constituent prices for pieces of land with specific functions, the equations need to be juxtaposed as in (1).

$$
C_{T j}=S_{1} \cdot c_{1}+S_{2} \cdot c_{2}+\cdots+S_{i} \cdot c_{i} \Leftrightarrow p_{j}
$$

Where:

$C_{T j}$ - transaction price for the whole $\mathrm{j}$-th property

$S_{i}$ - surface of the area with a specific function, as the i-th element of the $\mathrm{j}$-th property

$c_{i}$ - unit price of the $\mathrm{i}$-th element of the property

$p_{j}$ - weights of mutual similarity of properties used to construct the model which are determined from formula (2)

$$
p_{j}=\frac{1}{0.25+\sum_{s=1}^{n}\left(a_{j s}-\hat{a}_{s}\right)^{2}}
$$

Weights are determined assuming that in the database of real estate that is similar to the valuated property, the most representative real estate is that whose features are similar to their average values $\left(\hat{a}_{s}\right)$.

When all the attributes of real estate used to generate the model and features of the appraised property are identical, the weight matrix becomes an identity matrix, which significantly simplifies calculations.
Transaction prices (when necessary) have to be updated to the date of appraisal.

The unknown (parameters) in such an equation are the unit prices of the i-th element of the property. The system of equations (1) given in the matrix form for a few transaction prices that are similar to the one valuated take the form (3).

$$
\left\{C_{T}\right\}=\{S\} \cdot\{c\}+\left\{\delta_{T}\right\} \Leftrightarrow\{p\}
$$

Where:

$\left\{C_{T}\right\}$ - vector of transaction prices for entire properties

$\{S\}$ - rectangular vertical matrix made of surface areas of fragments of individual properties

$\{c\}$ - vector of unit prices of particular elements of the considered properties

$\left\{\delta_{T}\right\}$ - vector of the model random deviations to real estate transaction prices

$\{p\}$ - weight matrix of mutual similarity of the analysed properties.

The set of equations (3) meets Gauss-Markow's requirements (4). It has solutions in the set of real numbers, if the number of transactions ( $j$ ) is bigger than the sum of the considered elements of the real estate (i) and the number of attributes used to describe these properties (s).

$$
\begin{gathered}
E\left\{C_{T}\right\}=\{S\} \cdot\{c\} \Leftrightarrow E\left\{\delta_{T}\right\}=0 \\
E\left[\left\{\delta_{T}\right\}^{T} \cdot\left\{\delta_{T}\right\}\right]=V\left\{C_{T}\right\}=\sigma^{2} \cdot\{I\}
\end{gathered}
$$

Vector estimators of unit prices for the property elements $\{\hat{c}\}$ are derived directly from normal equations, according to formula (5).

$$
\{\hat{c}\}=\left(\{S\}^{T} \cdot\{p\} \cdot\{S\}\right)^{-1} \cdot\{S\}^{T} \cdot\{p\} \cdot\left\{C_{T}\right\}
$$

In contrast, the estimator of random deviations to transaction prices $\left\{\hat{\delta}_{T}\right\}$ derives from equation (6) by using formula (5) in formula (3)

$$
\left\{\hat{\delta}_{T}\right\}=\left\{C_{T}\right\}-\{S\} \cdot\left(\{S\}^{T} \cdot\{p\} \cdot\{S\}\right)^{-1} \cdot\{S\}^{T} \cdot\{p\} \cdot\left\{C_{T}\right\}
$$

In turn, the estimator of residual variance ( $\hat{\sigma}_{0}^{2}$ ) for model prices results directly from the model assumptions. It can be calculated from formula (7).

$$
\hat{\sigma}_{0}^{2}=\frac{\left\{C_{T}\right\}^{T} \cdot\{p\} \cdot\left\{C_{T}\right\}-\{\hat{c}\}^{T} \cdot\{S\}^{T} \cdot\{p\} \cdot\left\{C_{T}\right\}}{j-i-s}
$$


The formula for the covariance matrix of unit model prices vector $\{\hat{c}\}$ derives from the variance analysis and takes the form (8).

$$
\operatorname{Cov}\{\hat{c}\}=\hat{\sigma}_{0}^{2} \cdot\left(\{S\}^{T} \cdot\{p\} \cdot\{S\}\right)^{-1}
$$

The covariance matrix of random deviations vector to transaction prices derives from the analysis of the correlation variance (3). As a result, the covariance matrix of random deviations vector to transaction prices $\left\{\hat{\delta}_{T}\right\}$ is given in formula (9).

$$
\operatorname{Cov}\left\{\hat{\delta}_{T}\right\}=\hat{\sigma}_{0}^{2} \cdot\left(\{p\}^{-1}-\{S\} \cdot\left(\{S\}^{T} \cdot\{p\} \cdot\{S\}\right)^{-1} \cdot\{S\}^{T}\right)
$$

If all real estate used to construct the model and the appraised property have identical features, the market value of any property may be valuated with formula (10).

$$
W=S_{1} \cdot \hat{c}_{1}+S_{2} \cdot \hat{c}_{2}+\cdots+S_{i} \cdot \hat{c}_{i}
$$

This formula uses estimated unit values for individual elements of the property and surface areas of each component of the appraised property. When the appraisal relies on the model made of similar (but not identical) properties to the one being evaluated, the market value calculated from formula (10) needs to be corrected with formula (11).

$$
\hat{W}=W+\Delta W
$$

The correction of the real estate value is calculated as a weighted average of random deviations derived in the model from formula (12).

$$
\Delta W=\frac{\sum_{j=1}^{n} \delta_{T j} \cdot p_{j}}{\sum_{j=1}^{n} p_{j}}
$$

In this case, weights are calculated from formula (13)

$$
p_{j}=\frac{1}{0.25+\sum_{s=1}^{n}\left(a_{j s}-\bar{a}_{s}\right)^{2}}
$$

Where:

$\bar{a}_{s}$ - the s-th value of the appraised property attribute.

In order to calculate the inaccuracy of establishing the value of the appraised property, formula (14) is used.

$$
\sigma(\hat{W})=\sqrt{\left\{S_{W}\right\} \cdot \operatorname{Cov}\{\hat{c}\} \cdot\left\{S_{W}\right\}^{T}+\{P\} \cdot \operatorname{Cov}\left\{\hat{\delta}_{T}\right\} \cdot\{P\}^{T}}
$$

Where:

$\left\{S_{W}\right\}$ - vector of surface areas of the appraised property components

$\{P\}$ - vector whose components are the weights of individual real estate used for market analysis divided by the sum of these weights.

\subsection{Valuation algorithm in the conditional model}

The conditional model is also based on the analysis of prices obtained for the entire property. It should be used only when the number of transactions that concern real estate with heterogenous functions on a given market is smaller than the number of the analysed components of the real estate. Satisfactory results may be obtained only when it is possible to determine the approximate unit prices of the real estate components when taking into account the situation on the analysed real estate market. Calculations are justified only when all similar properties have identical attributes to the appraised property.

This appraisal model proved to be efficient in separating the value of land and buildings when valuating built-up properties (Parzych, 2009a), arable land when valuating agricultural properties (Parzych, 2008; Parzych, 2009a; Bydłosz et al., 2011) and different forest habitats when valuating forest plots (Parzych, 2008, Parzych, 2009a, Parzych 2009b). The application of this model was also proposed in the mass valuation (Parzych and Bydłosz, 2008). This model was used to evaluate real properties with various functions in (Bieda, 2018).

In order to divide the transaction price of land property that lies within the area of various functions into constituent prices for pieces of land with specific functions, the equations need to be juxtaposed as in (15).

$$
C_{T j}=S_{1} \cdot\left(\tilde{c}_{1}+\delta_{1}\right)+S_{2} \cdot\left(\tilde{c}_{2}+\delta_{2}\right)+\cdots+S_{i} \cdot\left(\tilde{c}_{i}+\delta_{i}\right)
$$

Where:

$C_{T j}$ - transaction price of the whole j-th property

$S_{i}$ - surface of the area with a specific function, as the i-th element of the $\mathrm{j}$-th property

$\tilde{c}_{i}$ - approximate unit value of the $\mathrm{i}$-th element of the property

$\delta_{i}-$ random deviation to approximate unit value of the i-th element of the property.

After the multiplication of relevant elements in equation (15) and their grouping, the conditional model of the property unit prices is obtained and presented in formula (16).

$$
\begin{aligned}
& S_{1} \cdot \delta_{1}+S_{2} \cdot \delta_{2}+\cdots+S_{i} \cdot \delta_{i}= \\
= & C_{T j}-S_{1} \cdot \tilde{c}_{1}-S_{2} \cdot \tilde{c}_{2}-\cdots-S_{i} \cdot \tilde{c}_{i}
\end{aligned}
$$

In equation (17) the independent term is the difference between the transaction price $\left(C_{T j}\right)$ for the property and the model price ( $C_{M j}$ ), which is the approximate value for the property. The formula for the model price takes the form (17).

$$
C_{M j}=S_{1} \cdot \tilde{c}_{1}+S_{2} \cdot \tilde{c}_{2}+\cdots+S_{i} \cdot \tilde{c}_{i}
$$

When calculating the approximate value of the unit prices for properties with uniform functions that have been traded, the local real estate market can be used. Hence, the value of the independent term $\left(\Delta C_{T j}\right)$ in equation (17) can be calculated on the basis of values obtained from formula (18).

$$
\Delta C_{T j}=C_{T j}-S_{1} \cdot \tilde{c}_{1}-S_{2} \cdot \tilde{c}_{2}-\cdots-S_{i} \cdot \tilde{c}_{i}=C_{T j}-C_{M j}
$$

After replacing the independent term in equation (16) with the symbol adopted in formula (18), the conditional model for the property unit prices takes the form (19).

$$
S_{1} \cdot \delta_{1}+S_{2} \cdot \delta_{2}+\cdots+S_{i} \cdot \delta_{i}=\Delta C_{T j}
$$

For a few similar properties, the set of equations may be juxtaposed and written symbolically in the matrix form (20). 


$$
\{S\} \cdot\{\delta\}=\{\Delta C\}
$$

Where:

$\{S\}$ - matrix generated from the surface area values of particular elements of the property

$\{\delta\}-$ vector of random deviations for the model unit valı property elements

$\{\Delta C\}$ - matrix generated from the difference between transaction prices and the approximate values for the considered properties. The set of equations (20) meets Gauss-Markow's requirements described with formulas (21).

$$
E[\{S\} \cdot\{\delta\}]=\{0\} \Leftrightarrow E\{\delta\}=0
$$

The estimator of random deviations vector $\{\hat{\delta}\}$ may be calculated from formula (22).

$$
\{\hat{\delta}\}=\{S\}^{T} \cdot\left(\{S\} \cdot\{S\}^{T}\right)^{-1} \cdot\{\Delta C\}
$$

The unit values of property elements $\left(\hat{c}_{i}\right)$ can be calculated from formula (23).

$$
\hat{c}_{i}=\tilde{c}_{i}+\delta_{i}
$$

The estimator of residual variance $\left(\hat{\sigma}_{0}^{2}\right)$ is calculated from formula (24).

$$
\hat{\sigma}_{0}^{2}=\frac{\{\hat{\delta}\}^{T} \cdot\{\hat{\delta}\}}{j}
$$

It is necessary to determine the covariance matrix $\operatorname{Cov}\{\hat{\delta}\}$ of random deviations, which can be calculated from formula (25).

$$
\operatorname{Cov}\{\hat{\delta}\}=\hat{\sigma}_{0}^{2} \cdot\left(\{S\}^{T} \cdot\left(\{S\} \cdot\{S\}^{T}\right)^{-1} \cdot\{S\}\right)
$$

For the covariance matrix of the unit values of the property elements, the following equation can be written (26).

$$
\operatorname{Cov}\{\hat{c}\}=\hat{\sigma}_{0}^{2} \cdot\left(\{I\}-\{S\}^{T} \cdot\left(\{S\} \cdot\{S\}^{T}\right)^{-1} \cdot\{S\}\right)
$$

The value of the valuated property $(\hat{W})$ is calculated from formula (27).

$$
\hat{W}=S_{1} \cdot \hat{c}_{1}+S_{2} \cdot \hat{c}_{2}+\cdots+S_{i} \cdot \hat{c}_{i}
$$

The assessment of inaccuracy with which the property value is determined is calculated from formula (28).

$$
\sigma(\hat{W})=\sqrt{\left\{S_{W}\right\} \cdot \operatorname{Cov}\{\hat{c}\} \cdot\left\{S_{W}\right\}^{T}}
$$

Where:

$\left\{S_{W}\right\}$ - vector of the surface areas of the appraised property components.

\section{RESULTS}

When valuating the property with the parametric model, all properties similar to the appraised property were considered. In order to determine the parameters of the conditional model, three properties with identical features to the valuated property were chosen (properties 3, 9, and 18).

\subsection{Results obtained in the parametric model}

Information from tables 1 and 3 enable the juxtaposition of 18 equations which were used to determine the unit values of areas with functions MD, PR, PG, and S (formula 29).

Due to the size of the matrix $\{p\}$, formula (30) includes only values which are on the matrix diagonal. Other values equal 0 .

As a result of the estimation of model parameters, values (30) were obtained.

On the basis of residual variance $\left(\hat{\sigma}_{0}^{2}\right)$, which amounted to 206,444,599 $\mathrm{PLN}^{2}\left(\hat{\sigma}_{0}=14,368 \mathrm{PLN}\right)$ the covariance matrix was determined $(\operatorname{Cov}\{\hat{c}\})$ for unit values of the property elements (31).

Elements on the matrix diagonal facilitate the calculation of standard deviations of the value $(\sigma(\hat{c}))$ for respective areas (32).

Other values obtained as a result of estimation of the model parameters comprise random deviations $\left(\hat{\delta}_{T}\right)$ to relevant transaction prices (33). They are presented along with their standard deviations $\left(\sigma\left(\hat{\delta}_{T}\right)\right)$, determined on the basis of covariance matrix $\left(\operatorname{Cov}\left(\hat{\delta}_{T}\right)\right)$.

Determined on the basis of the parametric model, the property value $\mathrm{W}=1,055,240 \mathrm{PLN}$ was corrected considering random deviations to transaction prices and the weight of mutual similarity between the valuated property and properties which comprise the model presented in formula (34).

Corrections to the previously calculated property value equal $\Delta W=578$ PLN. The final market value of the valuated property is $\hat{W}=1,055,818$ PLN. Standard deviation to the corrected value of the valuated property is $\sigma(\hat{W})=8,683 \mathrm{PLN}$, which constitutes approximately $1 \%$ of the valuated property value. 


$S=\left[\begin{array}{cccc}2,100 & 250 & 1,140 & 0 \\ 3,300 & 520 & 0 & 400 \\ 1,760 & 300 & 180 & 450 \\ 3,700 & 40 & 400 & 700 \\ 2,300 & 150 & 980 & 0 \\ 2,200 & 290 & 0 & 0 \\ 1,350 & 830 & 180 & 0 \\ 2,000 & 0 & 870 & 500 \\ 1,400 & 690 & 240 & 0 \\ 3,350 & 220 & 0 & 0 \\ 2,720 & 130 & 0 & 0 \\ 2,150 & 610 & 650 & 0 \\ 3,780 & 0 & 470 & 0 \\ 3,100 & 0 & 1,230 & 0 \\ 2,310 & 115 & 980 & 660 \\ 3,000 & 250 & 340 & 410 \\ 2,070 & 0 & 620 & 390 \\ 1,720 & 550 & 100 & 510\end{array}\right]\left[m^{2}\right]$

$\hat{c}=\left[\begin{array}{c|cc}399.02 & M D & \\ 151.92 & P R & \\ 54.94 & P G & {\left[P L N / m^{2}\right]} \\ 296.06\end{array}\right] S$

$$
\sigma(\hat{c})=\left[\begin{array}{c}
3.02 \\
12.13 \\
9.68 \\
14.56
\end{array}\right] \begin{array}{ll}
M D \\
P R \\
P
\end{array}\left[P L N / m^{2}\right]
$$

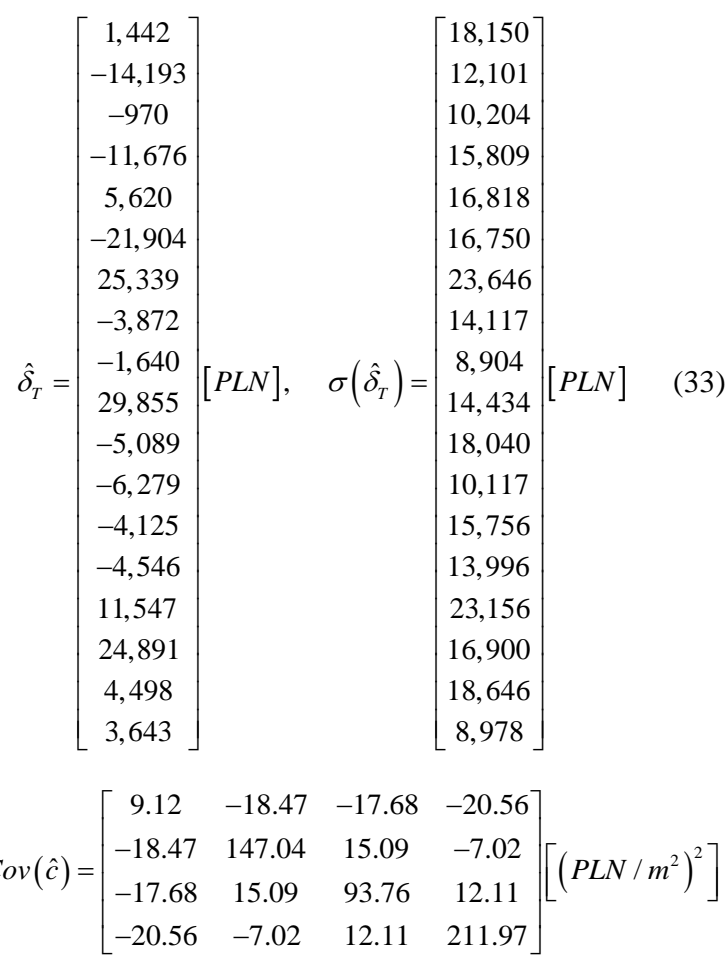

$C_{T}=$

$1,400,000$

$1,100,000$

980,000

$1,530,000$

$1,300,000$

$1,200,000$

$1,400,000$

980,000

930,000

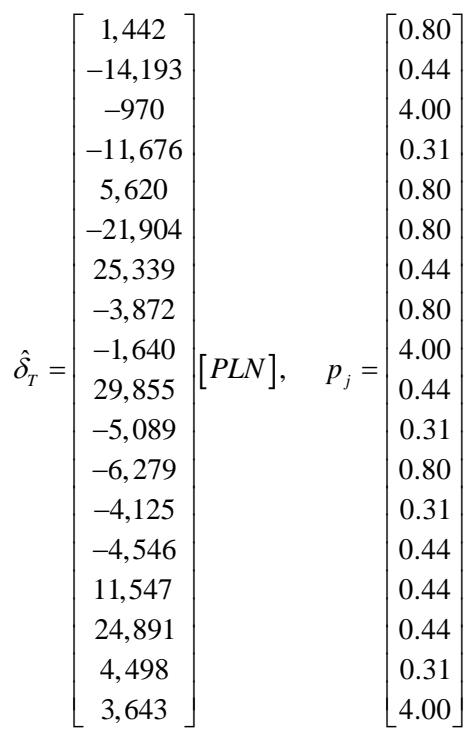

\subsection{Results obtained in the conditional model}

Information from table 3 enables the building of a matrix, which was used to determine the unit values of properties located in areas with functions MD, PR, PG, and S (formula 35).

In order to determine the approximate values of areas with specific functions, transaction prices were analysed for properties with uniform functions, which were sold in the same period as properties in the database created for comparison purposes on the same local market. Values calculated as arithmetic means from all recorded transactions were included in the matrix of approximate values (36).

On the basis of the matrix $\{S\}$ and the matrix of approximate values $\{\tilde{c}\}$ the model prices for individual properties $\left(C_{M j}\right)$ were determined along with price rises $\left(\Delta C_{T_{j}}\right)$, which were used to build a matrix of the independent term (37).

The results of solving equation (21) are deviations $\left(\hat{\delta}_{i}\right)$ to approximate unit values of relevant property elements (38). 
On the basis of determined deviations $\left(\hat{\delta}_{i}\right)$ and approximate unit values $\left(\tilde{c}_{i}\right)$, the values $\left(\hat{c}_{i}\right)$ were determined for respective areas (39).

Residual variance ( $\hat{\sigma}_{0}^{2}$ ) for the applied model is $269.68 \mathrm{PLN}^{2}$ ( $\hat{\sigma}_{0}=16.42 \mathrm{PLN}$ ). On its basis, the covariance matrices of random deviations (40) were determined, along with the unit values of property elements (41).

On the basis of the covariance matrix of random deviations it was possible to determine standard deviations $(\sigma(\hat{\delta}))$ of these random anomalies to approximate unit values (42).

A covariance matrix of unit values of the property elements was used in turn to determine the standard deviations $(\sigma(\hat{c}))$ of unit values of particular areas (43).

By using prices for individual areas which were determined with the conditional model, the value of the appraised property was established. The final price was calculated by using formula (27) and amounts to $\hat{W}=1,052,244$ PLN. The standard deviation is $\sigma(\hat{W})=1,053$ PLN, which constitutes approx. $0.1 \%$ of the determined market price.

$$
\begin{aligned}
& S=\left[\begin{array}{cccc}
1,760 & 300 & 180 & 450 \\
1,400 & 690 & 240 & 0 \\
1,720 & 550 & 100 & 510
\end{array}\right]\left[m^{2}\right] \\
& \tilde{c}=\left[\begin{array}{c}
403 \\
142 \\
57 \\
298
\end{array}\right]\left[P L N / m^{2}\right] \\
& \Delta C=\left[\begin{array}{c}
-6,240 \\
-860 \\
1,060
\end{array}\right][P L N] \\
& \left.\hat{\delta}=\left[\begin{array}{c}
9.06 \\
-21,15 \\
11,55
\end{array}\right] \begin{array}{l}
M D \\
P R \\
-12,08
\end{array}\right]\left[P L N / m^{2}\right] \\
& \hat{c}=\left[\begin{array}{c|c}
393.94 & M D \\
163.15 & P R \\
45.45 & P G \\
310.08
\end{array}\right]\left[P L N / m^{2}\right] \\
& \operatorname{Cov}(\hat{\delta})=\left[\begin{array}{cccc}
256.636 & 8.508 & 51.627 & 24.692 \\
8.508 & 264.130 & -33.674 & -16.105 \\
51.627 & -33.674 & 65.335 & -97.732 \\
24.692 & -16.105 & -97.732 & 222.937
\end{array}\right]\left[\left(P L N / m^{2}\right)^{2}\right]
\end{aligned}
$$

$\operatorname{Cov}(\hat{c})=\left[\begin{array}{cccc}13.043 & -8.508 & -51.627 & -24.692 \\ -8.508 & 5.549 & 33.674 & 16.105 \\ -51.627 & 33.674 & 204.344 & 97.732 \\ -24.692 & 16.105 & 97.732 & 46.742\end{array}\right]\left[\left(P L N / m^{2}\right)^{2}\right]$

$$
\begin{aligned}
\sigma(\hat{c}) & =\left[\begin{array}{c}
16.02 \\
16.25 \\
8.08 \\
14.93
\end{array}\right] \begin{array}{l}
M D \\
P R \\
P S
\end{array}\left[P L N / m^{2}\right] \\
\sigma(\hat{c}) & \left.=\left[\begin{array}{c}
3.61 \\
2.36 \\
14.30
\end{array}\right] \begin{array}{l}
M D \\
P R \\
6.84
\end{array}\right] S
\end{aligned}
$$

\section{DISCUSSION}

Because both the appraised property and the properties used for valuation are located mainly in areas designed for building multidwelling houses (MD), it is possible that many appraisers would decide to valuate such a property while neglecting its heterogeneous function. In such a case, the property value may be accepted as the arithmetic mean of unit prices ascribed to properties with identical features to the valuated property (Czaja, 2001). Three such properties were found (numbers 3, 9, and 18). Their average price is $314 \mathrm{PLN} / \mathrm{m}^{2}$. The price is determined with a standard deviation of $22 \mathrm{PLN} / \mathrm{m}^{2}$. The obtained value was compared with valuation results generated by the parametric and conditional model (table 4).

After multiplying the surface areas of particular parcels by their unit values from table 4 , the values for parcels of specific functions were obtained. Their sums provide the value of the whole property (table 5).

The values of appraised property in the parametric model and in the conditional model are similar, and the difference in price is 2,500 PLN for the whole property. The value of this same property assessed by comparing similar properties is nearly 50,000 PLN lower than the value obtained with statistical models. It constitutes approximately $5 \%$ of the property value. Moreover, depending on the calculation method, the shares of a particular area's value compare to the value of the entire property change (figure 1).

The most significant differences in the shares of particular area value in the value of the entire property may be noticed between the appraisals by comparison in pairs and two statistical methods. What is quite obvious is that the smallest differences may be observed in the areas designed for commercial and public services (S), whose unit value obtained with statistical models is similar to the value designated as the average price of properties identical to the valuated property. When applying statistical methods of appraisal, the unit value of areas designed for building multi-dwelling houses (MD) is higher than when applying the classical method. However, the unit value of areas for public roads (PR) and public greenery (PG) is lower. 
Table 4. Comparison of obtained unit values $\left[\mathrm{PLN} / \mathrm{m}^{2}\right]$

\begin{tabular}{|c|c|c|c|c|}
\hline valuation method & MD & PR & PG & 314 \\
\hline comparison in pairs & 314 & 314 & 314 \\
\hline parametric model & 399 & 152 & 55 & 296 \\
\hline conditional model & 394 & 163 & 45 & 311 \\
\hline
\end{tabular}

Table 5. Comparison of obtained values for the whole property $\left[\mathrm{PLN} / \mathrm{m}^{2}\right]$

\begin{tabular}{|c|c|c|c|c|c|}
\hline valuation method & MD & PR & PG & In total \\
\hline comparison in pairs & 659,400 & 78,500 & 94,200 & 172,700 & $1,004,800$ \\
\hline parametric model & 837,900 & 38,000 & 16,500 & 162,800 & $1,055,200$ \\
\hline conditional model & 827,400 & 40,750 & 13,500 & 171,050 & $1,052,700$ \\
\hline
\end{tabular}

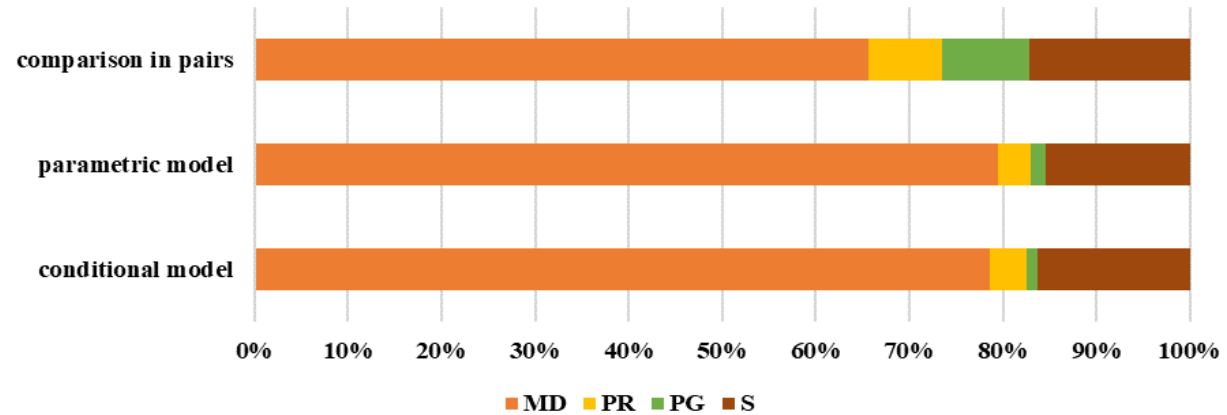

Figure 1. The share of particular areas value in the value of the entire property

\section{CONCLUSIONS}

The transaction price of the property is negotiated on the basis of the appraised value. Real estate value largely depends on the purposes the real estate is used for and also on its function in the planning documents.

Procedures for valuating properties that are compared to other properties should use real estate with the same function as the real estate being evaluated. However, because areas with different functions are not always determined according to lot borders, it often happens that real estate with non-uniform functions is subject to appraisal. It may happen that while searching for similar properties to the one being evaluated, properties which seem to have a similar function differ from the valuated property not only in the function of particular elements but also in the fact that they have different shares of areas with heterogeneous function.

The calculations presented in this article suggest the necessity of verifying whether the heterogeneous functions of real estate should be considered in their appraisal. The application of proposed statistical models of valuation makes the obtained value better reflect the actual condition. By indicating the true value of areas that can be invested in, potential buyers can be encouraged to decide on whether to conclude a transaction. The consequence of purchasing land for investment purposes will be taking prompt action to build housing on it. The area covered by planning actions will develop more rapidly, and if this development is in line with planning documents, it is considered sustainable development.

Obviously, sometimes the basic arithmetic mean is a more reliable appraisal method than the complex model (Adamczewski, 2006), but in properties with non-uniform functions, this rule does not always work (Bieda, 2017; Bieda, 2018).

It should be noted that the presented statistical methods of appraisal rely on the least squares method, which despite being the most widely used method of parameter estimation, is not very resistant to atypical cases and not very efficient for dealing with non-typical properties (Ligas, 2010). It means that even one odd observation can completely distort calculation results. Being aware of this fact is of particular importance when using the conditional calculation method, where the model is created on the basis of just a few properties. This means that correct use of these models is possible subject to conditions (Adamczyk et al., 2019).

In order to judge whether the proposed model can or should be commonly used, further analyses need to be carried out on different markets and for real estate with different functions.

\section{ACKNOWLEDGEMENTS}

This work was financed by research funds from the AGH University of Science and Technology, no. 16.16.150.545.

\section{References:}

Adamczewski, Z., 2006. Elementy modelowania matematycznego $w$ wycenie nieruchomości. Podejście porównawcze (Elements of Mathematical Modelling in Real Estate Valuation. Comparative Approach). Oficyna Wydawnicza Politechniki Warszawskiej, Warszawa.

Adamczewski, Z., Hopfer A., 2008. Trend udziału gruntu i budynku w wartości nieruchomości zabudowanej (Relationship of separated land and building value in built-up real estate 
valuation). Studia $i$ Materiaty Towarzystwa Naukowego Nieruchomości / Journal of the Polish Real Estate Scientific Society, 16(3), pp. 19-32.

Adamczyk, T., 2010. Estymacja rynkowych wartości wskaźników kosztu wytworzenia i zużycia łącznego obiektów budowlanych (Market value indicators estimation of cost of production and consumption of total conctructions). Kwartalnik Naukowy Państwowej Wyższej Szkoty Zawodowej w Jarosławiu, 1, pp. 29-39.

Adamczyk, T., Begović, V., Bieda, A., Bielecka, E., Bugaj, P., Dawidowicz, A., Džunić, I., Gajos, M., Jankowska, M., Kereković, D., Krukowska, K., Kryszk, H., Kurowska, K., Parzych, P., Rahmonov, O., Schrunk, I., Wójciak, E., Źróbek, R., 2014. Spatial data in wide geospace. Nacionalna knjižnica, Zagreb.

Adamczyk, T., Bieda, A., 2014. Intended Use of Real Estate as a Time Changeable Attribute for Determining Compensation for Nationalized and Expropriated Lands. Real Estate Management and Valuation, 22(4), pp. 35-50, DOI: 10.2478/remav-20140035 .

Adamczyk, T., Bieda, A., Parzych, P., 2019. Principles and criteria for using statistical parametric models and conditional models for valuation of multi-component real estate. Real Estate Management and Valuation, 27(2), in print.

Adamczyk, T., Dąbrowski J. 2010. Algorytm estymacji rynkowych wartości wskaźników kosztu wytworzenia i zużycia łącznego obiektów budowlanych posiadających różne okresy eksploatacji (Estimate algorithm of development cost and combine wear cost indicators associated with the market value of real properties with different exploitation time periods). Studia $i$ Materiaty Towarzystwa Naukowego Nieruchomości / Journal of the Polish Real Estate Scientific Society, 18(1), pp. 83-93.

Adamczyk, T., Jasiołek J., Podejście kosztowe w modelowaniu wartości rynkowej nieruchomości zabudowanych (Modelling of built-up properties market value based on cost approach). Studia i Materiaty Towarzystwa Naukowego Nieruchomości / Journal of the Polish Real Estate Scientific Society, 20(2), pp. 235-246.

Barkemeyer, R., Holt, D., Preuss, L., Tsang, S., 2014. What happened to the 'development' in sustainable development? Business guidelines two decades after Brundtland. Sustainable development, 22(1), pp. 15-32, DOI:10.1002/sd.521.

Basista, I., 2010. Wstępny projekt podsystemu geoinformatycznego do analizy rynku nieruchomości (Geoinformatic subsystem project for real estate market analysis). Studia i Materiaty Towarzystwa Naukowego Nieruchomości / Journal of the Polish Real Estate Scientific Society, 18(4), pp. 45-56.

Batóg, B., Foryś, I., Gaca, R., 2017. Spatial Autocorrelation in the Analysis of the Land Property Market on the Example of Szczecin and Bydgoszcz. Acta Universitatis Lodziensis. Folia Oeconomica, 3, pp. 33-43.

Bieda, A., 2017. Parametric model of real estate valuation for land located in different land-use zones. Geomatics and Environmental Engineering, 11(4), 17-33, DOI: 10.7494/geom.2017.11.4.17.
Bieda, A., 2018. Conditional model of real estate valuation for land located in different land use zones. Real Estate Management and Valuation, 26(1), pp. 122-130, DOI: 10.2478/remav-20180010 .

Bieda, A., Bieda, A., Adamczyk, T., Parzych, P., 2016. The procedure for the valuation of real properties developed with passive and energy-efficient houses. Proceedings of 16th International Multidisciplinary Scientific Geoconference, Albena, Bulgaria, vol. 2, pp. 633-640.

Bieda, A., Brzozowski, Ł., 2007, Analiza krakowskiego rynku nieruchomości gruntowych (Analysis of market of ground estates in Cracow). Geomatics and Environmental Engineering, 1(4), pp. 21-30.

Bieda, A., Hanus, P., Hycner, R., 2012. Geodezyjne aspekty planowania przestrzennego $i$ wybranych opracowań projektowych (Surveying aspects of land use planning and selected design studies). Wydawnictwo Gall, Katowice.

Bieda, A., Parzych, P., 2013. Development of spatial politics of monumental towns based on Krakow example, Proceedings of 13th International Multidisciplinary Scientific Geoconference, Albena, Bulgaria, vol. 2, pp. 143-150.

Bieda, A., Pukanská, K., Sala, B., 2018. Spatial Planning in Localities with Special Historic Values on Examples of Poland and Slovakia. Geomatics and Environmental Engineering, 12(1), pp. 5-27, DOI:10.7494/geom.2018.12.1.5

Busko, M., Szafranska, B., 2018. Analysis of Changes in Land Use Patterns Pursuant to the Conversion of Agricultural Land to Non-Agricultural Use in the Context of the Sustainable Development of the Malopolska Region. Sustainability, 10, 136, DOI: $10.3390 /$ su10010136.

Bydłosz, J., Parzych, P., Dąbrowski, J., 2011. The possibilities of real estate's market development in Poland in connection with INSPIRE directive. Geomatics and Environmental Engineering, 5(1), pp. 15-23.

Cellmer, R., Bełej, M., Źróbek, S., Kovac, M., S., 2014. Urban land value maps-a methodological approach. Geodetski vestnik, 58(3), pp. 535-551, DOI: 10.15292/geodetskivestnik.2014.03.535-551.

Chang, Y. C., Ko, T. T., 2014. An interactive dynamic multiobjective programming model to support better land use planning. Land Use Policy, 36, pp. 13-22. DOI:10.1016/j.landusepol.2013.06.009.

Chen, Z., Hu, Y., Zhang, C.J., Liu, Y., 2017. An Optimal Rubrics-Based Approach to Real Estate Appraisal. Sustainability, 9, 909, DOI: 10.3390/su9060909.

Choi, J., Hwang, M., Kim, G., Seong, J., Ahn, J., 2016. Supporting the measurement of the United Nations' sustainable development goal 11 through the use of national urban information systems and open geospatial technologies: a case study of South Korea. Open Geospatial Data, Software and Standards, 1(4), pp. 2-9. DOI: 10.1186/s40965-016-0005-0.

Cieślak, I., 2010. Analiza systemu planowania przestrzennego we Francji w nawiązaniu do systemu polskiego (A comparative analysis of the spatial planning system in france and in poland). 
Acta Scientiarum Polonorum, Administratio Locorum, 9(2), pp. 5-16.

Czaja, J., 2001. Metody szacowania wartości rynkowej i katastralnej nieruchomości (Methods of Estimating Market Value and Cadastral Value). Wydawnictwo KOMP-SYSTEM, Krakow.

Czaja, J., 1997. Modele statystyczne $w$ informacji o terenie (Statistical Models in Land Information). Wydawnictwo Akademii Górniczo-Hutniczej, Krakow.

Czaja, J., Parzych, P., 2008. Zaawansowane modele statystyczne wyceny nieruchomości zurbanizowanych (The Urbanized Estates Valuation Advanced Statistical Models for Mortgage Securing). Studia $i$ Materiaty Towarzystwa Naukowego Nieruchomości / Journal of the Polish Real Estate Scientific Society, 16(3), pp. 7-18.

Dawidowicz, A., Radzewicz, A., Renigier-Biłozor, M., 2014. Algorithm for purposes of determining real estate markets efficiency with help of land administration system. Survey review, 46(336), pp. 189-204, DOI: 10.1179/1752270613Y.0000000080.

Foryś, I., Kokot, S., 2008, Preferencje potencjalnych nabywców w określaniu wag cech rynkowych nieruchomości (The Potential Buyers Preferences in Defining the Property Attribute Scale). Studia i Materiaty Towarzystwa Naukowego Nieruchomości / Journal of the Polish Real Estate Scientific Society, 16(2), pp. 4560.

Fuseini, I., Kemp, J., 2015. A review of spatial planning in Ghana's socio-economic development trajectory: A sustainable development perspective. Land Use Policy, 47, pp. 309-320, DOI:10.1016/j.landusepol.2015.04.020.

Golej, J., 2012. Porovnanie systémov územného plánovania v Taliansku a na Slovensku (comparison of spatial planning systems in Italy and Slovakia). Nehnutelnosti a bývanie, 1, pp. $27-37$

Grădinaru, S.R., Iojă, C.I., Pătru-Stupariu, I., Hersperger, A.M., 2017. Are Spatial Planning Objectives Reflected in the Evolution of Urban Landscape Patterns? A Framework for the Evaluation of Spatial Planning Outcomes. Sustainability, 9, 1279, DOI: $10.3390 /$ su9081279.

Grzesik, C., Źróbek, R. 2017. Shifting Positions on Hope Value. Real Estate Management and Valuation, 25(3), pp. 23-29. DOI: 10.1515/remav-2017-0019.

Gupta, J., Vegelin, C., 2016. Sustainable development goals and inclusive development. International environmental agreements: Politics, law and economics, 16(3), pp. 433-448, DOI: 10.1007/s10784-016-9323-z.

Hajer, M., Nilsson, M., Raworth, K., Bakker, P., Berkhout, F., de Boer, Y., Rockström, J., Ludwig, K., Kok, M. 2015. Beyond Cockpit-ism: Four Insights to Enhance the Transformative Potential of the Sustainable Development Goals. Sustainability, 7, pp. 1651-1660, DOI: 10.3390/su7021651.
Koreleski, K., 2009. The system of spatial planning and land management in Poland. Geomatics and Environmental Engineering, 3(2), pp. 27-42.

Krajewska, M., Źróbek, S., Kovač, M. Š., 2014. The role of spatial planning in the investment process in Poland and Slovenia. Real Estate Management and Valuation, 22(2), pp. 5266, DOI: 10.2478/remav-2014-0017.

Kwartnik-Pruc, A., Przewięźlikowska, A. 2007. Porównanie funkcjonowania planowania przestrzennego w Polsce i w Niemczech (Comparison of physical planning functions in Poland and Germany). Geomatics and Environmental Engineering, 1(3), pp. 149-160.

Ligas, M., 2010. Metody statystyczne w wycenie nieruchomości (Statistical Methods in Real Estate Valuation). Studia i Materiaty Towarzystwa Naukowego Nieruchomości / Journal of the Polish Real Estate Scientific Society, 18(1), pp. 49-64.

Lorek, S., Spangenberg, J. H., 2014. Sustainable consumption within a sustainable economy: Beyond green growth and green economies. Journal of Cleaner Production, 62, pp. 33-44. DOI:10.1016/j.jclepro.2013.08.045.

Maliene, V., 2011. Specialised property valuation: Multiple criteria decision analysis. Journal of Retail \& Leisure Property, 9(5), pp. 443-450, DOI: 10.1057/rlp.2011.7.

Pagourtzi, E., Assimakopoulos, V, Hatzichristos, T., French, N., 2003. Real estate appraisal: a review of valuation methods. Journal of Property Investment \& Finance, 21(4), pp. 383-401, DOI: $10.1108 / 14635780310483656$.

Parzych, P., 2007. Modelowanie wartości nieruchomości zurbanizowanych (The Modeling of Urban Real Estates' Values). Studia i Materiaty Towarzystwa Naukowego Nieruchomości / Journal of the Polish Real Estate Scientific Society, 15(3-4), pp. 167-176.

Parzych, P., 2008. Warunkowe modele estymacji jednostkowych cen elementów nieruchomości (The Conditional Estimation Models for Unit Estates' Elements). Studia i Materialy Towarzystwa Naukowego Nieruchomości / Journal of the Polish Real Estate Scientific Society, 16(2), pp. 93-100.

Parzych, P., 2009a. Modele estymacji wartości rynkowej lub katastralnej nieruchomości zurbanizowanych, rolnych i leśnych (Estimation models of the market of cadastral value of urbanized, agricultural and forest estates). AGH Uczelniane Wydawnictwa Naukowo-Dydaktyczne, Krakow.

Parzych, P., 2009b. Warunkowy model estymacji jednostkowych cen dla nieruchomości leśnych (The conditional model of unit prices estimation for forest estates). Studia i Materiaty Towarzystwa Naukowego Nieruchomości / Journal of the Polish Real Estate Scientific Society, 17(1), pp. 47-57.

Parzych, P., 2011. Modelling of urban estates' values. Geomatics and Environmental Engineering, 5(4), pp. 63-72.

Parzych, P., Bydłosz, J., 2007. The Algorithm of Urban Estates Valuation. Proceedings of FIG Working Week 2007, Hong Kong, China. 
Parzych, P., Bydłosz, J., 2008. Problems of real estates' valuation for taxing purposes. Proceedings of FIG Working Week 2008, Stockholm, Sweden.

Parzych, P., Czaja, J., 2015. Szacowanie rynkowej wartości nieruchomości (Estimation of real estates market value). AGH Uczelniane Wydawnictwa Naukowo-Dydaktyczne, Krakow.

Preweda, E., 2013. Rachunek wyrównawczy $\Rightarrow$ modele statystyczne (Adjustment computations $\Rightarrow$ statistical models). Wydawnictwo PROGRES, Krakow.

Putek, E., 2001.Statystyczna analiza rynku nieruchomości w Gryfinie (Statistical Analysis of the Real Estate Market in Gryfino). Zeszyty Naukowe Uniwersytetu Szczecińskiego. Prace Katedry Ekonometrii i Statystyki, 10, pp. 221-228.

Radzewicz, A., Wiśniewski, R., 2012. Zmienne, cechy i atrybuty nieruchomości (Variables, Features and Attributes of Real Estate). Studia $i$ Materialy Towarzystwa Naukowego Nieruchomości / Journal of the Polish Real Estate Scientific Society, 20(1), pp. 5-15.

Rącka, I., 2009. Czynniki wpływające na wartość nieruchomości gruntowych niezabudowanych o przeznaczeniu mieszkaniowym jednorodzinnym na podstawie analizy kaliskiego rynku nieruchomości w latach 2003-2008. Biuletyn Stowarzyszenia Rzeczoznawców Majątkowych Województwa Wielkopolskiego, 3 , pp. 57-67.

Register of Real Estate Prices and Values kept by the Kraków City Office, access: 15.06.2016.

Renigier-Biłozor, M., Biłozor, A., Wisniewski, R., 2017. Rating engineering of real estate markets as the condition of urban areas assessment. Land Use Policy, 61, pp. 511-525, DOI: 10.1016/j.landusepol.2016.11.040.

Renigier-Biłozor, M., d’Amato, M., 2017. The Valuation of Hope Value for Real Estate Development. Real Estate Management and Valuation, 25(2), pp. 91-101, DOI: 10.1515/remav-2017-0016.

Stafford-Smith, M., Griggs, D., Gaffney, O., Ullah, F., Reyers, B., Kanie, N., Stigson, B., Shrivastava, P., Leach, M., O'Connell, D., 2017. Integration: the key to implementing the Sustainable Development Goals. Sustainability Science, 12(6), pp. 911-919. DOI: $10.1007 / \mathrm{s} 11625-016-0383-3$.

Tölle, A., 2014. Zintegrowane formy planowania i zarządzania rozwojem lokalnym a instrumentarium planistyczne - system polski na tle systemu niemieckiego (Integrated forms of planning and managing local development and the planning toolkit. The contrast between the Polish and the German system). Studia Regionalne i Lokalne / Regional and Local Studies, 57(3), pp. 6076, DOI: 10.7366/1509499535704.

Topczewska, T., 2012. Integrated planning of development and revitalisation of cities in selected countries of the European Union and in Poland. Człowiek $i$ Środowisko / Man and Environment, 36(3), pp. 21-40.

Waage, J, Yap, C, Bell, S, Levy, C, Mace, G, Pegram, T, Unterhalter, E, Dasandi, N, Hudson, D, Kock, R, Mayhew, S. H, Marx, C, Poole, N. 2015. Governing Sustainable Development Goals: interactions, infrastructures, and institutions. [In:] Waage,
J, Yap, C., Eds., Thinking Beyond Sectors for Sustainable Development, Ubiquity Press, London, pp. 79-88.

Wiśniewski, Z., 2005. Rachunek wyrównawczy w geodezji (Compensatory Account in Geodesy). Wydawnictwo Uniwersytetu Warmińsko-Mazurskiego, Olsztyn.

Zyga J., 2012. Istota podobieństwa w procedurach wyceny nieruchomości (Essence of Similarity in Real Estate Appraisal Procedures). Rzeczoznawca Majątkowy, 75(3), pp. 22-26.

Źróbek, S., Walacik, M., 2016. Real Estate Market Value in the Light of Valuation Practices. Świat Nieruchomości, 98(4), pp. 37-40. DOI: 10.14659/worej.2016.98.05. 